\title{
縮約モデルー骨組逆置換法に基づく骨組設計法 \\ FRAME DESIGN METHOD BASED ON REDUCED MODEL-FRAME INVERSE TRANSFORMATION
}

\author{
竹脇 出*1, 杉山哲彦*2, 过 聖晃*3, 上谷宏二*4 \\ Izuru TAKEWAKI, Tetsuhiko SUGIYAMA, Masaaki TSUJI \\ and Koji UETANI
}

\begin{abstract}
A method is proposed for designing member sizes of a frame which would satisfy the design constraints under Level-2 design earthquakes. This method consists of two steps. In the first step, a shear building model is used and story stiffnesses and story strengths of the shear model are determined so that the designed shear model would exhibit a specified distribution of interstory ductility factors under the Level-2 design earthquakes. In the second step, member sizes of the frame are transformed from the story stiffnesses and story strengths of the shear building model based on the proposed shear model-frame inverse transformation. In this transformation, the total member weight may be minimized as well as the equivalent transformation of the restoring force characteristics in the story level.
\end{abstract}

Keywords : high-rise building, elastic-plastic analysis, design sensitivity analysis, reduced model-frame inverse transformation, weight minimization 高層骨組, 弾塑性解析, 設計感度解析, 縮約モデル - 骨組逆置換法, 重量最小化

\section{1. 序}

建築構造設計の合理化を図るために, 最適構造設計や逆問題型アプ ローチを初めとして，これまでに種々の数理的な手法が提案されてい る（例えば[1-7]）。これらの数理的なアプローチは，前報[8]で述べた 種々の理由により，構造設計の実務において有効に用いられているよ うには見えない。しかしながら，多岐にわたる要求構造性能を実現す ることが求められている建築構造設計に扔いて, 数理的な手法の果た す役割が益々増大していることも事実であり，研究レベルと実務レベ ルの較差を小さくすることが強く求められている。

建築骨組の部材断面を骨組モデルを用いた設計法から直接決定す ることが可能であれば直接的であり望ましい。しかし，建築構造物は 立体構造物であり，高層骨組のような大規模構造物について，このよ うな部材レベルの特性を組み込んだモデルを種々の代替案の比較検 討が行われることの多い初期段階で扱うのは数值計算上有効ではな い。建築骨組の縮約モデルの一つである剪断型モデルに関しては, そ
の層レベルの復元力特性が骨組モデルの層レベルの復元力特性とあ る等価性条件を満足するとき，両者の地震時応答に良好な対応関係が 成立することがよく知られている（例えば[9]）。本論を含む一連の研 究では, 剪断型モデルを用いて層レベルでの設計クライテリアを満足 するように層レベルの力学特性（復元力特性）を決定し，縮約モデル 一骨組逆置換法により骨組部材断面を決定するという手法を提案す る。この置換法は, 高層建物の構造設計の実務において, 振動解析を 行う際に, 自由度の減少を目的として行なわれている骨組モデルから 剪断型モデルへの置換とは逆の置換を表している。

前報[8]では, 縮約モデル - 骨組逆置換法を展開する際に必要な基䃈 的な理論を展開し, 復元力特性上の点の設計感度表現をトータル量を 用いて求める方法を示した。設計感度のトータル量表現は, 増分型に よる表現や数值差分による手法よりも格段に有効かつ信頼性が高い。 本論では，このトータル量表現型設計感度解析を有効に利用し，剪断 型モデルを用いて設計された層レベルの復元力特性から実際に骨組
*1 京都大学大学院工学研究科建築学専攻 助教授. 工博

*2 奥村組 工修

*3 京都工芸繊維大学工芸学部造形工学科 助手・工博

*4 京都大学大学院工学研究科建築学専攻 教授・工博
Assoc. Prof., Dept. of Architecture and Architectural Systems, Graduate School of Eng., Kyoto University, Dr. Eng. Okumura Corp., M. Eng.

Research Assoc., Dept. of Architecture and Design, Faculty of Eng. and Design, Kyoto Institute of Technology, Dr. Eng.

Prof., Dept. of Architecture and Architectural Systems, Graduate School of Eng., Kyoto University, Dr. Eng. 


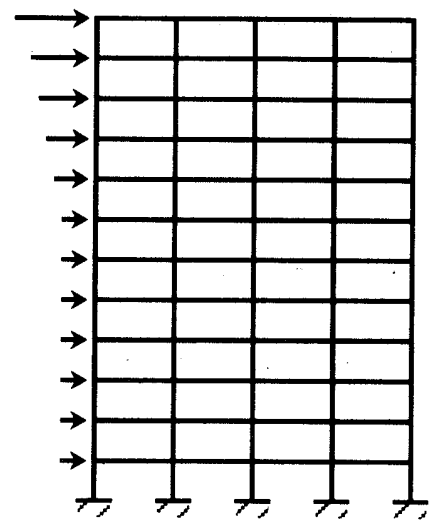

図 1 多層多スパン鋼構造平面骨組

の部材断面を決定する方法を展開する。

これまでに，建築骨組を力学的な意味で分割・合成する試みや剪 断型モデルから骨組モデルへと置換する研究は, 弾性問題や塑性極限 解析においてわずかに提案されているが $[1,10,11]$, 弾塑性域での復 元力特性を考慮に入れたものはほとんど見当たらない。本論を含む一 連の研究では，弾塑性域での復元力特性を一致させることを置換の際 の基準としで採用する。ただし，設計変数の数と拘束条件の数にも依 存するが, 剪断型モデルから骨組モデルへの置換が 1 対 1 対応ではな い場合には, 復元力特性を一致させることに加えて, 骨組の部材重量 を最小化することを置換の際の基準として採用する。

\section{2. 骨組モデル}

図 1 に示すような多層多スパンの鋼構造平面骨組を扱う。部材の剪 断変形，接合部変形は考慮しない。床版の面内変形は無視できるもの とする。従って, 同一層の節点の水平変位は同一とする。ここでは長 期荷重による断面力は考虑しない。また, 合成梁効果や長期荷重によ るP - $\Delta$ 効果も考虑しない。必要ならば，部材の両端における全塑性 モーメントの值を増減させることにより長期荷重による効果や合成 梁効果を取り入れることは容易である。また，P - $\Delta$ 効果も考慮可能 である。さらに，ここでは，本手法の骨格の単純明快な提示のため, 各部材は完全弾塑性部材から構成されるものとし，梁のみに塑性ヒン ジが形成される場合について解説する。正の第二分枝勾配が存在する 場合や，柱にも塑性ヒンジが形成される場合の取扱いについては前報

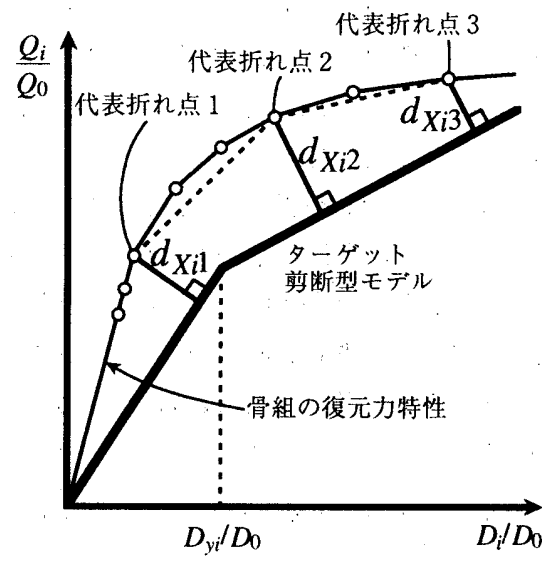

図 2 骨組モデルと剪断型モデルの 層剪断力 - 層間変位曲線
[8]を参照されたい。

骨組モデルの，或る水平荷重に対する単調載荷時の層剪断力－層間 変位曲線は塑性ヒンジの形成により図 2 のように折れ線で構成され る。その折れ線を単純化するために，折れ点の中から「代表折れ点」 を選定し，その代表折れ点を結んだ折れ線で層剪断力 - 層間変位曲線 を近似的に表現するものとする。一つの層剪断力 - 層間变位曲線上で 定義される代表折れ点の個数を $S$ で表す（図 2 では $S=3$ ）。実務では， しばしば，復元力特性の囲む面積の等価性を採用することもあるが， ここでは，塑性域では骨組モデルの復元力特性に内接するものとする。 以下では，骨組モデルの，或る水平荷重に対する単調載荷時の層剪断 力 - 層間変位曲線上の折れ点を単に「折れ点」と呼ふ。

\section{3. 縮約モデルの定義}

縮約モデルとしては剪断型モデルを操用する。剪断型モデルの復元 力特性としては, バイリニアー型でもトリリニアー型でもあるいはそ の他のモデルでも設定可能である。基本的に正勾配の折れ線から構成 されるものとする。

\section{4. 縮約モデル - 骨組逆置換法}

\section{1 縮約モデルー骨組逆置換問題}

綟約モデル - 骨組逆置換法を展開する際には, 両モデルの層剪断力 一層間変位関係における復元力特性の等価性を目標とする。ただし， 設計変数の数と拘束条件の数との関係により, 復元力特性の等価性だ けから骨組の各部材サイズを決定することができない場合には，復元 力特性の等価性と骨組部材重量の最小化の 2 点を目標とする。

ここでは， $N$ 層の骨組を扱い，いくつかの部材には共通の部材断面 を採用する（設計変数のグルーピング）。梁についての設計変数の数 を $f_{B}$, 柱についての設計変数の数を $f_{C}$ で表し, 全体としての総和を $f=f_{B}+f_{C}$ で表す。断面積 $A_{B j}$ を有する梁の部材長の総和を $L_{B j}$, 断面積 $A_{C j}$ を有する柱の部材長の総和を $L_{C j}$ で表す。

ここでは，上記の二つの目標が存在する場合について解説する。次 のような重み付き目標関数を最小化する問題を考える。

$$
C=C_{W}+C_{D}
$$

(1)式で $C_{W}$ は部材総体積を表し， $C_{D}$ は復元力特性の一致度を表す一 つの指標である両モデル（骨組モデルとターゲット剪断型モデル）の 復元力特性の距離の重み付き和を表している。 $C_{D}$ のみを考える場合 には $C_{W}=0$ とすればよい。

$$
\begin{aligned}
C_{W} & =\sum_{j=1}^{f_{B}} A_{B j} L_{B j}+\sum_{j=1}^{f_{C}} A_{C j} L_{C j} \\
C_{D} & =V_{0}\left(\sum_{i=1}^{N} \sum_{K=1}^{S} \beta_{X i K} d_{X i K}^{2}+\sum_{i=1}^{N} \sum_{K=1}^{S} \beta_{Y i K} d_{Y i K^{2}}{ }^{2}\right)
\end{aligned}
$$

ここで $d_{X i K}$ と $d_{Y i K}$ は， $X$ 方向構面と $Y$ 方向構面の第 $i$ 層の第 $K$ 代 表折れ点のターゲット剪断型モデルの復元力特性に对する無次元化 距離を表す（図 2 参照）。骨組復元力特性の代表折れ点が $D_{y i}$ より も 小さいときは第一分枝およびそれを延長した線への距離を求め， $D_{y i}$ よりも大きいときは第二分枝およびそれを延長した線への距離を求 めることとする。このルールは， $D_{y i}$ 近傍でやや精度が悪くなるが, 骨組復元力特性がターゲット剪断型モデルの復元力特性に十分近づ 
けば問題はなくなる。 $\beta_{X i K}, \beta_{Y i K}$ は， $d_{X i K}, d_{Y i K}$ に対する重み係数 を表す。また， $V_{0}$ は， $C_{W}$ との次元を一致させるための定数であり， 体積の次元を有している。

ここでは, 柱に塑性ヒンジが形成されない場合を扱うため, 柱 - 梁 耐力比制約を設定する。

\section{2 連続設計変数に対する最適化手法}

前報[8]では, 連続設計変数に対する問題を解くための基本的な考え 方を提示した。前報[8] 6 節の方法は, 設計変数の数が制約条件の数よ りも少ない場合には適用できないため，より一般的な方法について解 説する。連続設計変数に対する最適化手法の一つとして最急降下法が 存在する。最急降下法においては, 設計変数べクトル $\mathbf{x}=\left\{x_{1} \cdots x_{i} \cdots x_{f}\right\}^{T}$ は, 目標関数の勾配べクトル $\mathbf{g}$ を用いて次のよう に更新される。

$$
\mathbf{x}=\mathbf{x}-\varepsilon \mathbf{g}
$$

ここで, $\boldsymbol{\varepsilon}$ はステップ長を表し， $\mathbf{g}$ は

$$
\mathbf{g}=\left\{\frac{\partial C}{\partial x_{1}} \cdots \frac{\partial C}{\partial x_{i}} \cdots \frac{\partial C}{\partial x_{f}}\right\}^{T}
$$

$C$ は図 2 の代表折れ点の座標の関数であり, 代表折れ点の座標の設計 感度は, 前報[8]の(23)式から求められる。

第 $i$ 層，第 $k$ 折れ点の座標を $\left(D_{i k}(\mathbf{x}), Q_{i k}(\mathbf{x})\right)$ で表すことにする。設 計変数の更新に伴うこれらの折れ点の変動を, 次のような 1 次項まで を採用した Taylor 展開近似で評価する。

$$
\begin{aligned}
& D_{i k}(\mathbf{x}+\Delta \mathbf{x})=D_{i k}(\mathbf{x})+\sum_{j=1}^{f} \frac{\partial D_{i k}}{\partial x_{j}} \Delta x_{j} \\
& Q_{i k}(\mathbf{x}+\Delta \mathbf{x})=Q_{i k}(\mathbf{x})+\sum_{j=1}^{f} \frac{\partial Q_{i k}}{\partial x_{j}} \Delta x_{j}
\end{aligned}
$$

折れ点を特徵づける塑性ヒンジの生成順序が変化する場合には，入 れ替わる点で一旦解析を止め, 折れ点の座標のトータル量表現を求め る式の情報（塑性ヒンジの形成箇所）を更新しなければならない（前 報[8]の(20)式）。(5), (6)式の線形近似で一定の精度を保持するには, 多数回の繰り返し計算が必要となる。連続变数としての取扱いは理論 的な根拠を与えるものの, 実際に用いるには, (i)Taylor 展開の 2 次近 似表現を探用してステップ幅を大きくする,(ii)Taylor 展開の 1 次近似 による誤差項をできる限り取り除くための処理をする等の数值的効 率化における工夫が必要である。

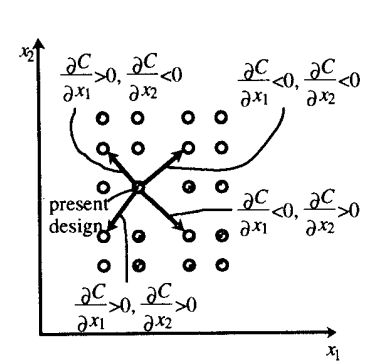

[アルゴリズム 1]

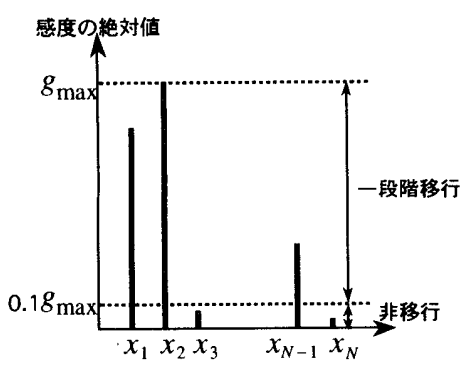

[アルゴリズム 2]
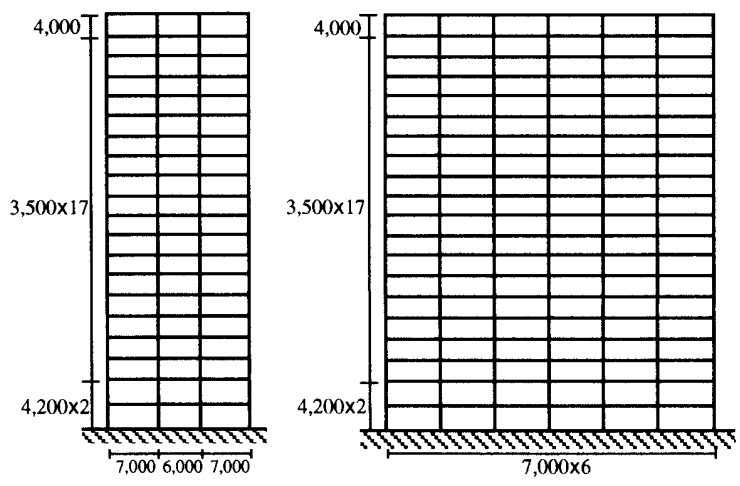

図 420 層モデル骨組（X 方向 3 スパン, $\mathrm{Y}$ 方向 6 スパン $)$

\section{3 離散最適化}

現実に採用できる部材断面は離散的である。また, 施工上の制約か ら部材の断面せいを特定のものにしたいという要求も存在する場合 がある。ここでは, 部材断面りストを用意し, その中から最適な断面 を決定する方法を採用する。設計者は部材断面りストを用意する際に， 断面せいや幅厚比等の要求を満たすものを用意すればよい。離散最適 化問題については，種々の方法が提案されている（例えば[12]）。最 もよく採用されているのは, 連続変数としての最適解を近似的に求め た後に, その周辺で離散変数を生成し, 分枝限定法や, GA(Genetic Algorithm)あるいは SA(Simulated Annealing)法を利用する方法である。 しかしながら, 本論で扱うような問題に対して連続変数としての取扱 いを直接適用するのは数值計算上有効ではない。そこで，直接的に離 散変数としての扱いを採用する。ただし, (4) 式の目標関数の設計变数 に関する勾配ベクトルを求めるときにおいてのみ一時的に連続変数 としての近似的な扱いをする。ここでは, 目標関数の勾配べクトルの 成分の符号に応じて一段階離れた隣接断面へと移行する次のような 2 種類のアルゴリズムを採用する（図 3 参照）。

[アルゴリズム 1] 目標関数の勾配ベクトル $\mathbf{g}$ の成分の符号に応じて， 全ての設計変数を一段階離れた隣接断面へと移行する。

[アルゴリズム 2] 目標関数の勾配ベクトル $\mathbf{g}$ を求め, 成分の絶対值 の最大值を求める。その最大值の 1 割より大きな勾配べクトル成分絶 対值に対応する設計変数はその成分の符号に応じて一段階離れた隣 接断面へと移行する。1 割以下の成分に対応する設計変数はそのまま の値とする。

離散最適化においては, 断面を更新した後に静的弾塑性解析を行う 必要がある。ただし，前報[8]で Q-D 曲線上の点のトータル量表現が 得られているため，それを用いることにより，静的弾塑性解析の回数 を減らすことも可能である。この方法については後続論文で扱う。

\section{4 水平 2 方向構面同時最適化}

建築構造物は 3 次元構造物であるため, 水平 2 方向構面の応答制約 条件を満足するものの中から部材断面を決定する必要がある。ここで は，柱としては正方形の箱型断面部材を採用し，梁としては 2 方向構 面ともH型断面部材を探用する。

図 3 アルゴリズム 1 とアルゴリズム 2 

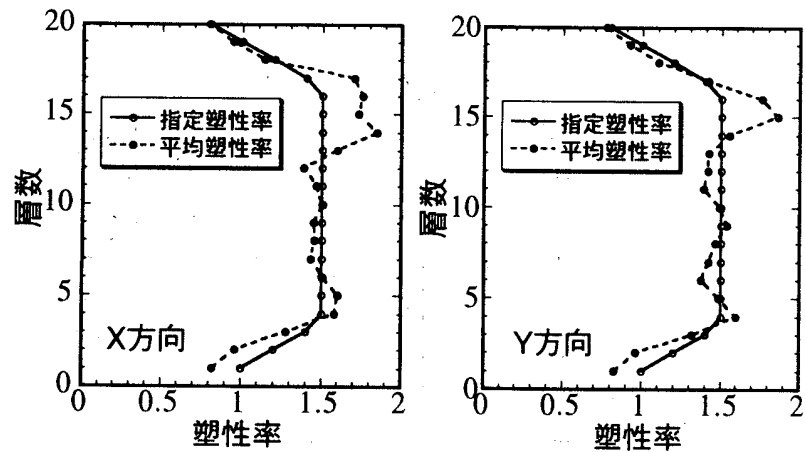

図 5 指定塑性率と制約設計剪断型モデルの人工地震波 10 波 に対する平均塑性率

表 1 短辺・長辺方向の諸量

\begin{tabular}{|c|c|c|c|c|c|c|c|c|}
\hline 階数 & $\begin{array}{l}\text { 降仸 } \\
\text { 変位 }\end{array}$ & & & & & 位率 & $\begin{array}{r}\text { 第一S } \\
\text { (tor }\end{array}$ & $\begin{array}{l}\text { 支剛性 } \\
\mathrm{cm} \text { ) }\end{array}$ \\
\hline & 短辺 & 長辺 & 短辺 & 長辺 & 短辺 & 長辺 & 短辺 & 長辺 \\
\hline 20 & 2.04 & 1.51 & 0.20 & 0.17 & 0.80 & 0.80 & 26.8 & 74.7 \\
\hline 19 & 2.19 & 1.71 & 0.13 & 0.23 & 1.00 & 1.00 & 37.3 & 99.8 \\
\hline 18 & 2.50 & 1.99 & 0.15 & 0.23 & 1.20 & 1.20 & 38.0 & 101 \\
\hline 17 & 2.68 & 2.17 & 0.13 & 0.32 & 1.40 & 1.40 & 37.7 & 99.5 \\
\hline 16 & 2.68 & 2.22 & 0.19 & 0.23 & 1.50 & 1.50 & 41.1 & 107 \\
\hline 15 & 2.50 & 2.09 & 0.17 & 0.17 & 1.50 & 1.50 & 49.5 & 128 \\
\hline 14 & 2.53 & 2.14 & 0.13 & 0.25 & 1.50 & 1.50 & 53.9 & 138 \\
\hline 13 & 2.58 & 2.19 & 0.18 & 0.32 & 1.50 & 1.50 & 57.4 & 146 \\
\hline 12 & .58 & 2.22 & 0.26 & 0.32 & 1.50 & 1.50 & 61.5 & 155 \\
\hline 11 & 2.60 & 2.19 & 0.18 & 0.33 & 1.50 & 1.50 & 65.2 & 168 \\
\hline 10 & 2.45 & 2.17 & 0.15 & 0.23 & 1.50 & 1.50 & 73.2 & 180 \\
\hline 9 & 2.42 & 2.19 & $0: 17$ & 0.18 & 1.50 & 1.50 & 77.7 & 188 \\
\hline 8 & 2.45 & 2.25 & 0.18 & 0.19 & 1.50 & .1 .50 & 79.9 & 191 \\
\hline 7 & 2.40 & 2.27 & 0.22 & 0.20 & 1.50 & 1.50 & 84.6 & 197 \\
\hline 6 & 2.27 & 2.17 & 0.19 & 0.24 & 1.50 & 1.50 & 92.7 & 213 \\
\hline 5 & 2.09 & 1.99 & 0.14 & 0.17 & 1.50 & 1.50 & 105 & 240 \\
\hline 4 & 2.07 & 2.04 & 0.14 & 0.13 & 1.50 & 1.50 & 109 & 242 \\
\hline 3 & 2.04 & 2.09 & 0.12 & 0.10 & 1.40 & 1.40 & 122 & 259 \\
\hline 2 & 2.23 & 2.50 & 0.17 & 0.13 & 1.20 & 1.20 & 126 & 254 \\
\hline 1 & .35 & 1.40 & 0.11 & 0.14 & 1.00 & 1.00 & 260 & 546 \\
\hline
\end{tabular}

表 2 初期部材断面

\begin{tabular}{|c|c|c|c|}
\hline & 柱(Box) & \multicolumn{2}{|c|}{ 梁(Wide-flange) } \\
\hline & & 短辺 & 長辺 \\
\hline $1 \sim 2$ 層 & $800 \times 800 \times 28$ & $800 \times 300 \times 16 \times 25$ & $800 \times 300 \times 16 \times 25$ \\
\hline $3 \sim 5$ 層 & $800 \times 800 \times 28$ & $800 \times 300 \times 16 \times 25$ & $800 \times 300 \times 16 \times 25$ \\
\hline $6 \sim 10$ 層 & $750 \times 750 \times 19$ & $800 \times 250 \times 14 \times 25$ & $800 \times 250 \times 14 \times 25$ \\
\hline $11 \sim 15$ 層 & $700 \times 700 \times 19$ & $750 \times 250 \times 12 \times 22$ & $750 \times 250 \times 12 \times 22$ \\
\hline $16 \sim 20$ 層 & $650 \times 650 \times 16$ & $750 \times 200 \times 9 \times 16$ & $750 \times 200 \times 9 \times 16$ \\
\hline
\end{tabular}

\section{5. 設計例題}

\section{1 剪断型モデルによる弾望性応答制約設計}

図 4 に示すような骨組を扱う。短辺方向を X 方向, 長辺方向を $\mathrm{Y}$ 方向とする。 $\mathrm{X}$ 方向の層質量は, 全層同一で $112(\mathrm{ton}), \mathrm{Y}$ 方向の層 質量も全層同一で 218(ton)とする。ここでは, 文献[7]の方法を若干改 修した方法を用いて，レベル 2 地震動に対して指定した弾塑性応答を 示す剪断型モデルの層剛性および対応する強度を決定する。

レベル 2 地震動に対する制約としては通常, 層の塑性率が 2 以下,

層間変形角が $1 / 100$ 以下という条件が設定される場合が多いため，こ こでも同様の制約を設定する。レベル 2 地震動としては, 設計用スペ クトル適合地震動を採用する。設計用スペクトルは Newmark と Hall
表 3 柱と梁の断面りスト（断面 2 次モーメントで表示）

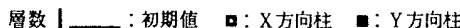
$\left(\times 10^{5} \mathrm{~cm}^{4}\right)$

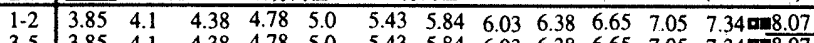

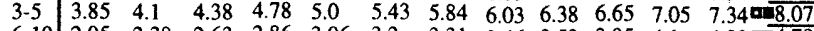
\begin{tabular}{lllllllllllll}
$6-10$ & 2.05 & 2.38 & 2.63 & 2.86 & 3.06 & 3.2 & 3.31 & 3.46 & 3.53 & 3.85 & 4.1 & 4.38 \\
\hline
\end{tabular}

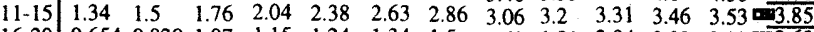
\begin{tabular}{l|lllllllllllll}
$16-20$ & 0.654 & 0.829 & 1.07 & 1.15 & 1.24 & 1.34 & 1.5 & 1.63 & 1.81 & 2.04 & 2.22 & 2.38 & $\mathbf{2 . 6 3}$
\end{tabular}

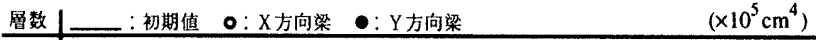
\begin{tabular}{l|lllllllllllll}
$1-2$ & 1.32 & 1.41 & 1.555 & 1.69 & $\bullet 1.84$ & 1.9 & 02.08 & 2.21 & 2.41 & 2.54 & 2.61 & 2.77 & 2.85 \\
\hline
\end{tabular}

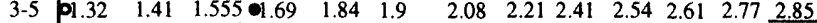
$\begin{array}{lllllllllllllll}6-10 & 0.686 & 0.831 & 0.976 & 1.17 & 01.32 & 1.41 & \bullet 1.555 & 1.69 & 1.84 & 1.9 & 2.08 & 2.21 & 2.41\end{array}$

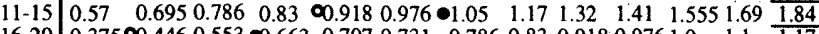
\begin{tabular}{l|llllllllllll}
$16-20$ & 0.37500 .446 & 0.553 & 0.663 & 0.707 & 0.731 & 0.786 & 0.83 & 0.918 & 0.976 & 1.0 & 1.1 & $\frac{1.84}{1.17}$
\end{tabular}

の提案するスペクトル[13]を採用し，地動最大速度は $50(\mathrm{~cm} / \mathrm{s})$ とする。 剪断型モデルの復元力特性としてはノーマルバイリニア型を採用す る。降伏層間変位と第 2 分枝剛性比は，5.2 節に示す初期骨組の静的 弾塑性解析から評価し，剪断型モデルの設計においては固定された量 として扱う。その降伏層間变位と第 2 分枝剛性比を表 1 に示す。表 1 には併せて，指定した層塑性率分布と弾塑性応答制約設計により得 られた層剛性分布（第一分枝剛性）を示す。本弾塑性応答制約設計の 精度を調べるために，応答スペクトルに適合する人工地震波を 10 波 作成し，得られたバイリニア型履歴特性を有する剪断型モデルに対す る時刻歴応答解析を実施した。そのときの塑性率の平均値を図 5 に示 す。層ごとに第二分枝剛性比にかなりばらつきがあるため，指定した 分布から少しばらついた分布を示している。

\section{2 縮約モデルー骨組逆置換法による骨組部材サイズの決定}

設計変数としては, 部材の断面 2 次モーメントを探用し, 柱と梁と 別々に数層ごとのグルーピングを行う。グルーピングは表 2 に示す通 りである。また，候補となる断面は表 3 のようにそれぞれのグループ について 13 種類設定する。ここでは, 設計変数の設定に際し, 外柱 と内柱は同じ部材を用いるものとし，梁についても同一㕌では各方向 ごとに同一の部材を用いる。4.3 節で述べたように，QD曲線上の点 のトータル量表現を用いて静的弾塑性解析の回数を減らすことも可 能であるが,ここでは, 離散的な断面変更ごとに静的弾塑性解析を実 施している。

初期骨組としては, 表 2 （および表 3の下線）に示すような部材断 面を採用した。この初期骨組は文献[14]の剛性設計法により求められ た部材サイズを最も近い離散断面へと切り上げることにより求めた。 設計感度解析を行うには, 柱や梁の断面諸量を設計変数を用いて関数

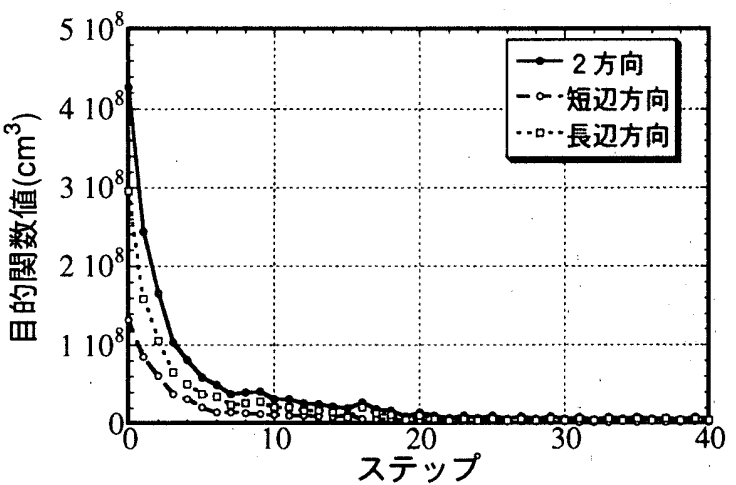

図 6 目標関数値の変動 

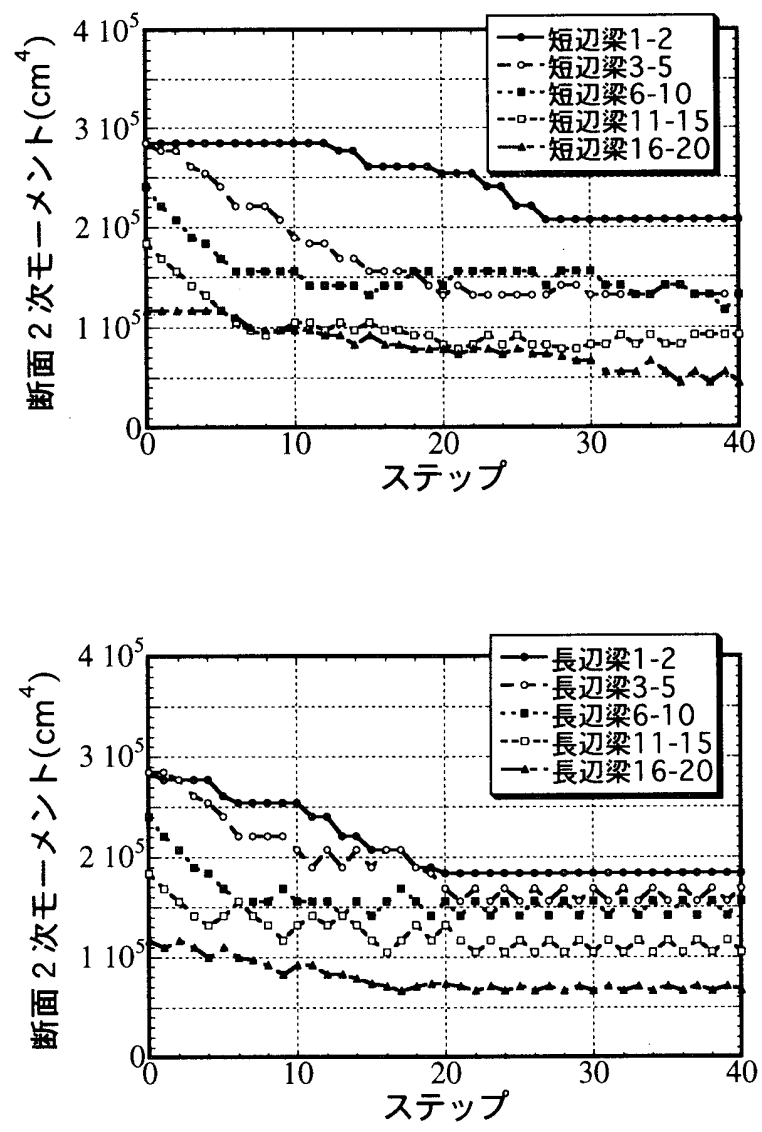

図 $7 \mathrm{X}$ 方向 (短辺) 梁とY方向 (長辺) 梁の 断面 2 次モーメントの変動
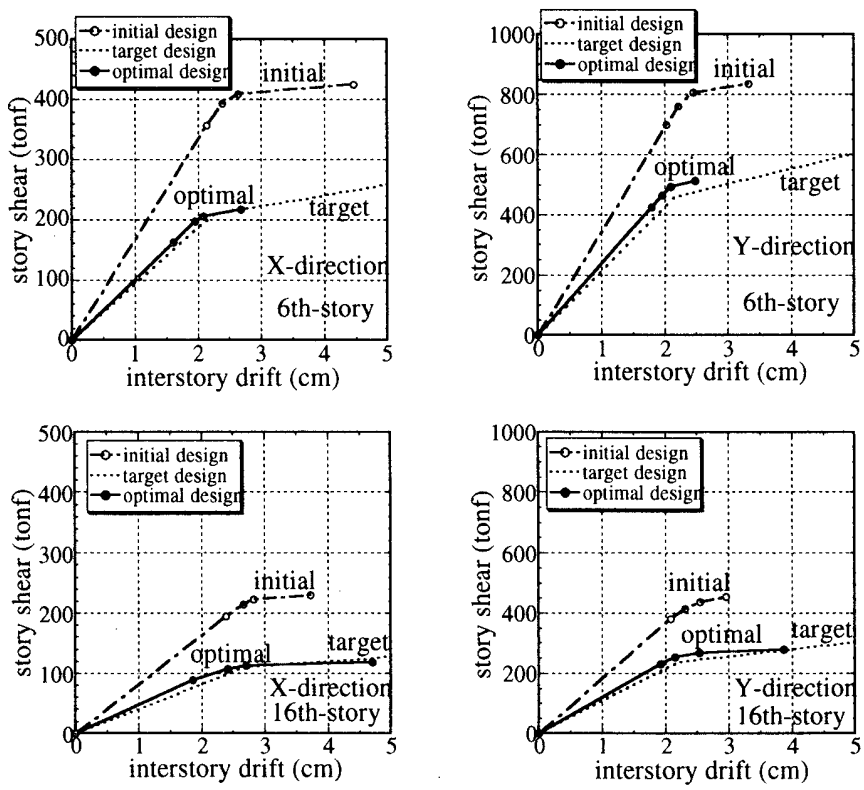

図 8 初期骨組, ターゲット設計, 最適化骨組に対する $\mathrm{x}$ 方向 と Y 方向の層前断力 - 層間変位関係の代表例 $(6,16$ 層)

表現しておく必要がある。ここでは柱の断面積 $A_{C}\left(\mathrm{~cm}^{2}\right)$ と梁の断面 積 $A_{B}\left(\mathrm{~cm}^{2}\right)$ は, 設計変数の柱の断面 2 次モーメント $I_{C}\left(\mathrm{~cm}^{4}\right)$ と梁の 断面 2 次モーメント $I_{B}\left(\mathrm{~cm}^{4}\right)$ を用いて近似的に次式で表されるとす る。
表 4 最終部材断面

\begin{tabular}{|c|c|c|c|}
\hline & 柱 $($ Box $)$ & \multicolumn{2}{|c|}{ 梁(Wide-flange) } \\
\hline & & 短辺 & 長辺 \\
\hline $1 \sim 2$ 層 & $800 \times 800 \times 28$ & $750 \times 250 \times 14 \times 25$ & $750 \times 250 \times 12 \times 22$ \\
\hline $3 \sim 5$ 層 & $800 \times 800 \times 28$ & $750 \times 200 \times 9 \times 19$ & $750 \times 200 \times 12 \times 25$ \\
\hline $6 \sim 10$ 層 & $750 \times 750 \times 19$ & $750 \times 200 \times 9 \times 19$ & $750 \times 200 \times 12 \times 22$ \\
\hline $11 \sim 15$ 層 & $700 \times 700 \times 19$ & $600 \times 200 \times 12 \times 22$ & $650 \times 200 \times 9 \times 22$ \\
\hline $16 \sim 20$ 層 & $650 \times 650 \times 16$ & $500 \times 250 \times 9 \times 12$ & $500 \times 200 \times 12 \times 25$ \\
\hline
\end{tabular}
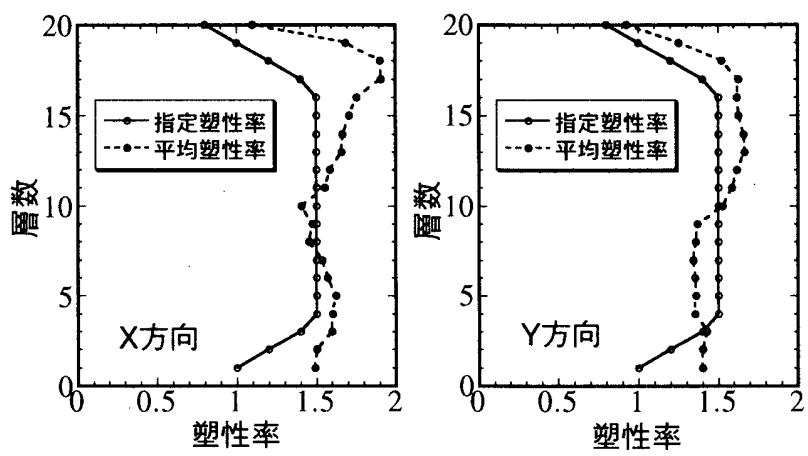

図 9 指定層塑性率と剪断型モデルで表現された最終骨組の 人工地震波 10 波に対する平均層塑性率
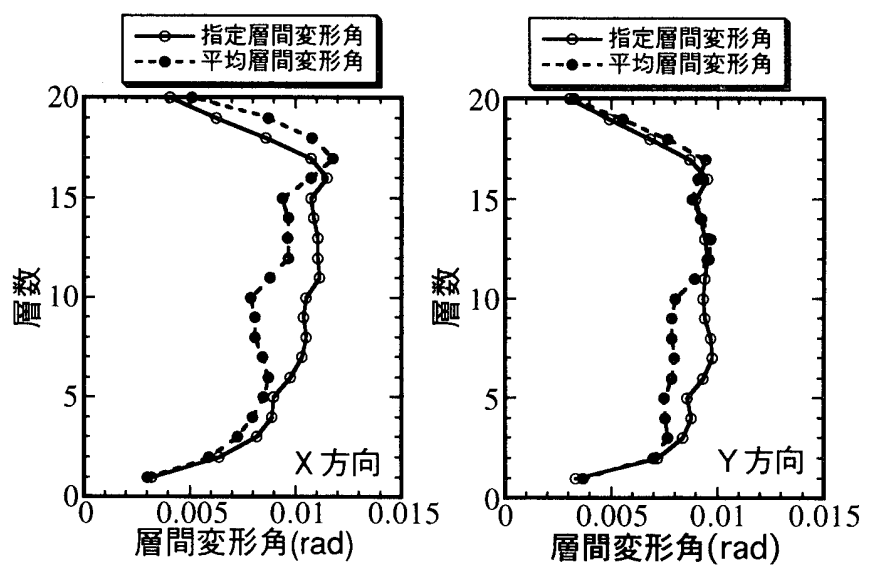

図 10 指定層間変形角と剪断型モデルで表現された最終骨組の 人工地震波 10 波に対する平均層間変形角

$$
A_{C}=0.8412 \sqrt{I_{C}}, \quad A_{B}=0.8496 \sqrt{I_{B}}
$$

また，梁の全塑性モーメント $M_{P}(N \cdot \mathrm{cm})$ は， $I_{B}$ を用いて近似的に次 式で表されるとする。

$$
M_{P}=0.0382 \sigma_{Y} I_{B} / d_{0} \quad\left(d_{0}=1 \mathrm{~cm}\right)
$$

さらに $\sigma_{Y}=2.35 \times 10^{4}\left(N / \mathrm{cm}^{2}\right), \quad E=2.06 \times 10^{7}\left(\mathrm{~N} / \mathrm{cm}^{2}\right), Q_{0}=$ $100($ tonf $), D_{0}=1(\mathrm{~cm}), V_{0}=1 \times 10^{6}\left(\mathrm{~cm}^{3}\right), \quad \beta_{X i K}=\beta_{Y i K}=1.0$ (for all $i$ and $K)$ とする。ここでは，(1)式の目標関数において，第二項の復元 力特性の等価性を要求する項のみを考慮し，重量を考慮しない最適化 を実施した。その理由は，本問題では，設計変数の数は 15 であり， $\mathrm{X}, \mathrm{Y}$ 両方向の復元力特性に関する条件（バイリニアーとして 2 個 $\mathrm{x} 2$ 構面 $\mathrm{x} 20$ 層=80 個）の数よりも少ないからである。多構面から構成さ れ，設計変数の数が増加する場合には重量を考慮する必要がある。

水平荷重の基準ベクトル $\mathbf{P}$ として, 多くの場合, 予備応答解析結 果等に基づく設計用荷重を採用するが，ここでは，X，Y両方向とも $A_{i}$ 分布から得られるものを採用する。代表折れ点としては, $\mathrm{X}$ 方向で 
は, 第 $1,8,30,45$ 折れ点の 4 点, $\mathrm{Y}$ 方向では, 第 $1,39,60,80$ 折れ 点の 4 点を採用する。

目標関数で定義する目標復元力特性としては，5.1 節で得られた剪 断型モデルの復元力特性を採用する。図 6 には，上記の離散最適化の アルゴリズム 2 を採用した場合の, 目標関数のステップ数に対する変 動の様子を示す。図には(2b)式の短辺, 長辺各方向の復元力特性の一 致度も示している。表 4 には, 最終的に得られた部材断面を示す（最 小目標関数を与えるもの)。また, 図 7 は, X,Y 両方向の設計変数で ある断面 2 次モーメントの変動をステップ数に対して描いた図を表 す。本例題では, 復元力特性の等価性のみを要求しており, 柱は目標 関数におよほす感度が低いため, 初期設計から変化していない。

図 8 には，初期骨組，ターゲット設計，最適化骨組の 3 種類のモデ ルに対する，X方向と $\mathrm{Y}$ 方向の層剪断力 - 層間変位関係の代表例 $(6$, 16 層) を示す。ここでは, 設計変数グルーピングを採用しているため, 層剪断力 - 層間変位関係を各層で精度よく一致させるのには限界が あり，数層ごとの平均的な意味で等価性条件が満足される点に注意す る必要がある。図 8 において, 初期骨組と最適化骨組の復元力特性上 の丸印は，代表折れ点を表している。最初の丸印は第 1 折れ点（骨組 のどこかで初めて塑性ヒンジが形成される状態に対応する層間変 位）を表している。表 1 に示す降伏層間変位を求める際には，実務設 計で通常行なわれるように，層の復元力特性を描き，勾配が初期弾性 勾配から異なりはじめる点の变位を採用している。この点は必ずしも 骨組に初めて塑性ヒンジが形成される点とは対応しない。つまり，遠 く離れた層で塑性ヒンジが形成されても当該層の復元力特性にはあ まり顕著な影響が表れないことはしばしば発生する（例えば文献 [15]）。従って, 図 8 の夕ーゲット復元力の降伏変位と初期骨組や最 適化骨組の最初の丸印は表現しているものが異なることに注意する 必要がある。

得られた骨組に対する静的弾塑性解析を実施し, 剪断型モデルの初 期剛性, 降伏層間変位, 第二分枝剛性比を再度求め, その剪断型モデ ルの前記人工地震波 10 波に対する時刻歴応答解析を実施した。その ときの平均塑性率分布を図 9 に示す。図 5 のターゲット剪断型モデル に対する時刻歴解析結果とほほ同レべルの偏差にとどまっているこ とがわかる。最終骨組を剪断型モデルにモデル化したときの降伏層間 変位は, 初期骨組を剪断型モデルにモデル化したときの降伏層間変位 とは異なるため, 図 9 の層塑性率の比較だけでは層間変形角がどれく らい一致しているかを把握することができない。そこで, 雨モデルで 異なる降伏層間変位を用いて層間変形角を評価したときの，指定層間 変形角（表 1 の降伏層間変位と指定塑性率の積）と, 剪断型モデルで 表現された最終骨組の人工地震波 10 波に対する平均層間変形角を図 10 に示す。層間変形角で表現した場合には，指定値と応答值は層塑性 率の場合よりも精度が向上しているのがわかる。X 方向（短辺方向） で層間変形角 $1 / 100$ を僅かに超過しているが, 層塑性率を少し小さめ に指定することによりその条件を満足させることも可能である。通常 は重大な問題が発生しない限りこの程度の超過は許容される場合が 多い。

参考として, (1)式の目標関数において, 第二項の復元力特性の等価 性に加えて重量も考慮した最適化を同様の手法により実施した。その 結果, 柱の部材断面は重量を考慮しない場合よりもやや小さくなり, 復元力特性の一致度はやや低下寸ることが明かとなった。
さらに, 4.3 節のアルゴリズム 1 についても検討したが, アルゴリ ズム 1 では感度の大きさを適切に考慮できないため，必ずしも目標関 数を有効に減少させる方向に向かわない場合があることがわかった。

\section{6. 結論}

本論では，弾塑性域での復元力特性を考慮し，剪断型モデルを用い て設計した層レベルでの特性を，維約モデル－骨組逆置換法により骨 組の部材断面へと置換する新しい方法を展開した。得られた成果は以 下の通りである。

（1）復元力特性上の点（代表折れ点）のトータル量表現型設計感度表 現（前報[8]で誘導）を有効に用いることにより，ターゲットとなる剪 断型モデルの復元力特性にできる限り一致するような骨組の部材断 面を決定する方法が展開できる。設計变数の数と制約条件の数に関連 して, 復元力特性の等価性条件のみから一意に骨組の部材寸法を決定 することができない場合には，復元力特性の等価性条件と部材重量最 小化を同時に設計目標とする必要がある。

（2）離散的な設計変数を採用した場合の最適化手法として，二つのシ ンプルなアルゴリズムを提案した。目標関数の勾配べクトルの成分の 符号に応じてすべて一段階異なる断面へ移行する第一の方法は，断面 の離散化刻み量や感度の大きさを適切に考虑できないが，第二の方法 では，感度の大きさにより移行の有無を判断するため，ある程度好ま しい変更が可能となる。離散的な設計変数を採用することにより, 増 分型静的弾塑性解析や, 目標関数の設計感度計算の回数を激減させる ことが可能となる。

（3）本手法によると, 水平 2 方向構面に対する部材断面を同時に決定 することが可能である。

本論文では, 平面骨組が並列に存在する多構面の場合やチューブ構 造，連層壁を有する骨組構造を扱っていないが，本論文で提示した基 本的な考え方はこのようなモデルについても拡張できるものと期待 している。その他の設計用荷重に対する制約条件も考慮に入れた取扱 いについては後続論文で提示する予定である。

謝辞 本研究に際し，大崎 純博士（京都大学助教授），田川 浩氏 (京都大学助手) および岡本達雄博士 (竹中工務店)，若松和範氏 (同) から貴重な助言を頂戴した。ここに記して謝意を表する。また，本研 究の一部は, 平田奖学金および文部省科学研究費（課題番号 10555201）による。

\section{参考文献}

[1] 中村恒善, 建築骨組の最適設計，丸善, 1980 .

[2] Tsuneyoshi Nakamura and T.Yamane, Optimum design and earthquake-response constrained design of elastic shear buildings. Earthquake Engng. \& Struct. Dyn., Vol.14, pp797-815, 1986.

[3]中村 恒善, 小坂 郁夫: 弾塑性骨組の指定設計用変形指標に対す る2 段階地震応答制約設計法, 日本建 築学会構造系論文報告集, 第 439 号, pp89-101, 1992.

[4] Tsuneyoshi Nakamura and Y.Nakamura : Stiffness Design of 3-D Shear Buildings for Specified Seismic Drifts, J. Struct. Engng. ASCE, Vol.119, pp50-68, 1993.

[5] 内村 均, 佐藤和英, 和田 章, 黒正清治, 水平変形に注目した 鉄骨骨組の部材断面変更法, 日本建築学会構造系論文集, 第 485 号, pp73-80, 1996

[6] 澤田樹一郎, 中村雄治, 松尾 彰, 反復線形計画法を用いた平面 ラーメンの最適弾性・塑性設計法, 日本建築学会構造系論文集, 第 485 号, pp117-125, 1996. 
[7] 長岡佳代子, 辻 聖晃, 弾塑性多層剪断型構造物の地震時層間変 位指定設計, 日本建築学会近畿支部研究報告集（平成 7 年度）, pp329-332, 1995.

[8] 上谷宏二, 竹脇 出: 綟約モデル - 骨組逆置換法のためのトー夕 ル量表現型設計感度解析, 日本建築学会構造系論文集, 第 511 号（揭 載決定) , 1998 .

[9] 中村恒善, 上谷宏二, 小坂郁夫, 竹脇 出：建築耐震設計におけ る保有耐力と変形性能(1990)「定義および算定法」，日本建築学会， 1990.

[10] V.V.Bertero and H.Kamil : Nonlinear Seismic Design of Multistory Frames, Canadian J. Civil Eng., 2, pp494-516, 1975.

[11] 秋山 宏, 建築物の耐震極限設計, 東京大学出版会, 1987 .

[12] M.-W.Huang and J.S.Arora, Optimal design of steel structures using standard sections, Structural Optimization, Vol.14, pp24-35, 1997.

[13] N.M.Newmark and W.J.Hall, Earthquake Spectra and Design, EERI, 1982.

[14] I.Takewaki : Efficient Semi-Analytical Generator of Initial Stiffness Designs for Steel Frames under Seismic Loading (Part 1 Fundamental frame) (Part 2 Slender frame), J. of The Structural Design of Tall Buildings, Vol.6, No.2, pp151-162, pp163-170, 1997.

[15] 竹脇 出：高層建築骨組の実用動的解析における諸問題 (Part II) 筋違付骨組とその等価剪断型モデルの弾塑性時刻歴応答解析, 日本建 築学会近畿支部構造力学講究録第 3 号, pp15-24, 1988.

(1998年 5 月 8 日原稿受理, 1998 年 8 月 21 日採用決定) 